\title{
TATUAGEM POR AMÁLGAMA - ESTUDO DE CASO
}

Talita Izabela Caliman RODRIGUES, Larissa FONDAZZI, Eduardo MORESCHI, Vanessa VELTRINI

Tatuagem por amálgama é uma lesão iatrogênica, que ocorre após a implantação traumática de partículas de amálgama nos tecidos moles. Pode apresentar coloração preta, cinza ou azulada e bordas definidas, irregulares ou difusas. É comum na região de gengiva, mucosa alveolar e mucosa jugal. Possui tamanho variável, sendo geralmente assintomática. Radiograficamente, só será observada se as partículas forem de tamanho suficiente para gerar imagem radiográfica. Microscopicamente, revelam-se fragmentos no interior do tecido conjuntivo, que marcam preferencialmente as fibras reticulares, especialmente as que cercam nervos e vasos. O propósito deste trabalho foi a análise do caso clínico da paciente do gênero feminino, 38 anos, cor branca, que compareceu ao projeto de lesões do CESUMAR com a queixa de "mancha escura na gengiva". Ao exame físico intrabucal, verificou-se a presença de pigmentação arroxeada em mucosa alveolar, na altura do ápice do dente 11 , com cerca de $2 \mathrm{~cm}$, superfície lisa e limites indefinidos. Realizou-se biópsia excisional, com hipótese diagnóstica de tatuagem por amálgama, o que se confirmou histologicamente. A lesão não requer tratamento, a menos que haja razão estética, psíquica ou dúvida quanto ao diagnóstico, já que, em alguns casos, outras pigmentações exógenas devem ser consideradas, além de lesões melanóticas e melanocíticas. 